\title{
Penggunaan Smartphone dalam Pembelajaran Kimia SMA
}

\author{
Irwanto $^{1,2}$ \\ ${ }^{1}$ Program Doktoral Ilmu Pendidikan, Universitas Negeri Yogyakarta, 55281, Indonesia \\ Email: Irwanto.2016@student.uny.ac.id \\ ${ }^{2}$ Received: 1 January 2016Received in revised form: 15 February 2016Accepted:25 February 2016
}

\begin{abstract}
ABSTRAK
Era digital memberikan berbagai kemudahan bagi guru dan siswa dalam melaksanakan kegiatan pembelajaran. Salah satu perangkat teknologi informasi yang dapat dimanfaatkan dalam pembelajaran yaitu smartphone. Penelitian ini bertujuan untuk mengetahui sejauh mana penggunaan smartphone dalam menunjang keberhasilan pembelajaran kimia di kalangan siswa. Jenis penelitian ini merupakan mixed methods, yaitu sebuah metode untuk mengumpulkan data kualitatif dan kuantitatif. Survey dilaksanakan di SMA Budya Wacana Yogyakarta dan SMA Tiga Maret Yogyakarta. Sampel berjumlah 53 siswa SMA kelas X yang berusia antara 15-18 tahun. Instrumen penelitian menggunakan kuesioner yang dimodifikasi dari Rossing et al. (2012). Kuesioner terdiri atas 10 item skala Likert dan 3 item pertanyaan terbuka. Data dianalisis secara deskriptif kualitatif untuk memperoleh informasi tentang penggunaan smartphone dalam mendukung proses pembelajaran. Hasil penelitian menunjukkan bahwa siswa menggunakan smartphone untuk mendukung program pembelajaran di dalam dan di luar kelas. Dengan demikian, guru perlu membimbing, mengarahkan, memfasilitasi dan mengoptimalkan penggunaan smartphone secara positif untuk meningkatkan motivasi dan hasil belajar siswa.
\end{abstract}

Kata kunci: smartphone, pembelajaran, kimia.

\section{Pendahuluan}

Perkembangan teknologi informasi dan komunikasi yang semakin pesat dapat dimanfaatkan guru untuk menunjang proses pembelajaran kimia. Dengan kata lain, pembelajaran kimia tidak lagi hanya disampaikan dengan metode ekspositori dimana siswa hanya menjadi pembelajar pasif, namun guru harus memfasilitasi siswa untuk belajar secara mandiri. Hal ini sesuai pendapat Chuang (2014) yang menyatakan bahwa pemanfaatan teknologi dalam pembelajaran akan meningkatkan motivasi dan hasil belajar siswa. Selain itu, pemanfaatan teknologi dapat digunakan sebagai media pembelajaran yang dapat diakses kapan saja dan dimana saja menggunakan media portabel seperti smartphone (Herrington, 2008). Dengan demikian, proses pembelajaran dapat dilaksanakan secara interaktif, inspiratif, menyenangkan, dan memotivasi siswa dengan menggunakan media pembelajaran berbantuan teknologi.

Pemanfaatan teknologi informasi dalam pembelajaran dikategorikan ke dalam Pendidikan Jarak Jauh (PJJ). PJJ diatur tersendiri dalam Peraturan Menteri Pendidikan dan Kebudayaan Nomor 72 Tahun 2013 tentang Pendidikan Layanan Khusus yang menyebutkan bahwa PJJ merupakan pendidikan yang 
siswanya terpisah dari guru dan pembelajarannya menggunakan berbagai sumber belajar melaluiteknologi komunikasi, informasi, dan media lain.Sistem PJJ memberikan akses yang luas terhadap dunia pendidikan bagi siapa saja untuk belajar di mana saja dan kapan saja. Siswa diberikan kebebasan untuk mencari pengetahuan melalui berbagai sumber informasi secara mandiri maupun berkelompok. Dalam implementasinya, PJJ membutuhkan perangkat pembelajaran mobileyang praktis serta didukung dengan teknologi yang memadai, salah satunya adalah smartphone.

Seperti yang telah kita ketahui, dampak positif era digital sudah merambah hingga perangkat mobile. Hal tersebut terlihat dari banyaknya sistem operasi pada perangkat mobile, seperti BlackBerry OS, iOS, dan Android. Pembelajaran mobile tersebut dapat berupa media pembelajaran interaktif, $e$ learning, dan software berbasis android yang dapat dioperasikan menggunakan smartphone. Pembelajaran dengan menggunakan bantuan smartphone berpotensi membantu siswameningkatkan motivasi belajar (Hess, 2014). Apabila peluang tersebut dapat dimanfaatkan secara tepat, maka pembelajaran akan menjadi lebih fleksibel dan interaktif. Implikasinya, pembelajaran tidak lagi didominasi oleh guru, sehingga siswa memiliki peran dalam menentukan kesuksesan belajar. Pembelajaran yang menarik tentu akan memudahkan siswa dalam memahami konsep kimia yang tergolong sulit dan abstrak.

Tren terbaru dalam e-learningdewasa ini dikenal sebagai Mobile Learning(M-Learning). Konsep pembelajaran tersebut menggunakan media portabel seperti smartphone dengan sistem operasi android. Sistem operasi android merupakan salah satu jenis terbaru dari sistem operasi perangkat komunikasi mobile (Martono \& Nurhayati, 2014). M-Learning berbasis android menggabungkan dan menghubungkan antara teknologi dan konten pendidikan. M-learning dapat digunakan sebagai solusi untuk memecahkan masalah dalam sistem pembelajaran tradisional. Dengan kata lain, M-Learning dapat digunakan untuk meningkatkan sistem pembelajaran secara keseluruhan (Sarrab, Elgamel, \& Aldabbas, 2012).

Sampai saat ini, android merupakan salah satu sistem operasi yang masih menjadi pilihan utama masyarakat. Perkembangan android yang begitu pesat mengindikasikan adanya kemenarikan fitur dan kemudahan dalam penggunaannya. Jumlah pengguna android di Indonesia periode Juli 2017 mencapai 84,09\% yang mengalami peningkatan dibandingkan tahun 2016 sebesar 73,80\% (StatCounter, 2017). Android merupakan sistem operasi yang paling populer digunakan oleh masyarakat, khususnya kalangan siswa. Namun kenyataannya, penggunaan smartphone oleh siswa belum dimaksimalkan untuk menunjang pembelajaran (Woodcock, Middleton, \& Nortcliffe, 2012). Kondisi tersebut terlihat dari penggunaannya sebatas hiburan maupun media sosial. Padahal perangkat mobile ini dapat digunakan sebagai media pembelajaran yang dapat digunakan kapan saja dan dimana saja (Meister, 2011).

Hasil penelitian yang dilakukan Parise \& Crosina (2012) dan Boyinbode \& Fasunon (2015) menunjukkan bahwa media teknologi merupakan suplemen dalam pembelajaran di kelas yang memberikan pengaruh signifikan terhadap peningkatan pembelajaran kolaboratif dan kerja sama tim. Media teknologi memberikan ruang gerak bagi siswa untuk berkomunikasi antarsiswa maupun dengan guru secara cepat. Oleh karena itu, penelitian ini bertujuan untuk mengetahui sejauh mana penggunaan perangkat mobile dalam menunjang program pembelajaran kimia. Hasil studi eksplorasi ini diharapkan dapat memberikan informasi bagi guru dan siswa dalam merencanakan dan menyelenggarakan kegiatan pembelajaran yang lebih efektif dan efisien.

\section{Metode Penelitian}

Penelitian ini menggunakan metode campuran (mixed methods) untuk mengumpulkan data kualitatif dan kuantitatif. Survey dilaksanakan di SMA Budya Wacana Yogyakarta dan SMA Tiga Maret Yogyakarta pada bulan Mei-Juni di semester genap tahun pelajaran 2016/2017. Sampel berjumlah 53 siswa SMA kelas X yang berusia antara 15-18 tahun dengan rincian 19 siswa laki-laki (35,8\%) dan 34 siswa perempuan (64,2\%). Instrumen penelitian menggunakan kuesioner dari Rossing et al. (2012) yang tersedia melalui internet di laman http://josotl.indiana.edu/. Kuesioner tersebut dimodifikasi menjadi 10 item skala Likert dan 3 item pertanyaan terbuka yang disajikan dalam Google Forms. Pertanyaan terbuka digunakan untuk memperoleh alasan siswa secara detail dalam memberikan respons. Sebelum pelaksanaan survey, siswa diberikan instruksi untuk mengisi kuesioner secara on-line melalui laman yang telah disediakan. Data dianalisis menggunakan statistik deskriptif dengan bantuan SPSS 23 untuk 
memperoleh informasi tentang penggunaan smartphone dalam mendukung proses pembelajaran. Hasil penelitian dideskripsikan berdasarkan temuan, ditafsirkan, kemudian disimpulkan secara kualitatif didukung dengan teori-teori yang relevan.

\section{Hasil dan Pembahasan}

Smartphone atau dikenal sebagai telepon pintar merupakan pengembangan dari telepon genggam yang mempunyai berbagai fitur canggih untuk memudahkan pengguna dalam berkomunikasi dan mengakses berbagai informasi secara cepat dalam masyarakat modern. Penggunaan smartphone telah menjadi bagian dari gaya hidup masyarakat Indonesia dalam segala aspek, salah satunya dunia pendidikan. Hasil penelitian menunjukkan bahwa seluruh responden (100\%) memiliki smartphone dengan berbagai merk dan spesifikasi. Dari 53 responden, sebanyak 52 siswa (98,1 \%) menggunakan smartphone untuk tujuan pembelajaran, sedangkan hanya 1 siswa (1,9\%) yang menggunakannya untuk tujuan lain, seperti chatting dan bermain game. Visualisasi jumlah pengguna smartphone dalam pembelajaran kimia disajikan pada Gambar 1.

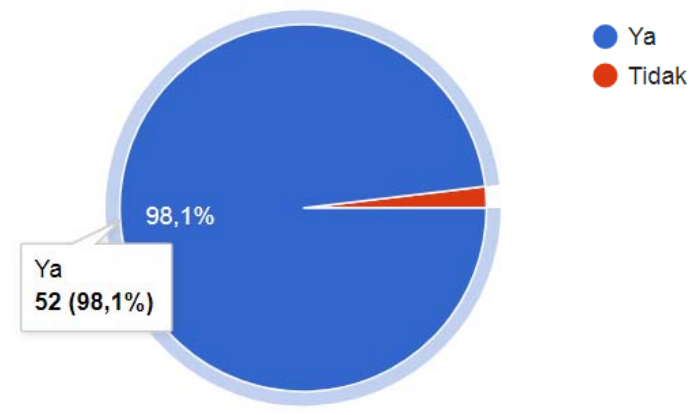

Gambar 1. Persentase pengguna smartphone

Penggunaan smartphone secara positif dapat menunjang kegiatan pembelajaran sekaligus memberikan pengalaman belajar secara menarik dan meningkatkan motivasi siswa terhadap kimia. Siswa dituntun untuk mencari masalah, menyelesaikan masalah, hingga menemukan solusi atas permasalahan tersebut menggunakan bantuan smartphone. Dampak pembelajaran yang diharapkan muncul dari penggunaan smartphone terbimbing berupa kemandirian belajar. Hasil tersebut diperkuat oleh penelitian yang dilakukan Yang \& Che (2015) menunjukkan bahwa penggunaan perangkat mobile seperti smartphone dapat menciptakan iklim pembelajaran yang lebih menarik, efektif, dan memicu motivasi belajar siswa ${ }^{1}$. Lebih lanjut, penggunaan mobile learning juga memberikan dampak yang signifikan terhadap kinerja akademik siswa ${ }^{2}$ (Sundari, 2015).

Frekuensi penggunaan smartphone. Berbagai fitur yang tersedia dalam smartphone memberikan kesempatan kepada siswa untuk mencari informasi kapan saja dan dimana saja tanpa batasan ruang dan waktu. Hasil penelitian menunjukkan sebanyak 51 siswa (96,2\%) mengaku menggunakan smartphone setiap hari, sedangkan 2 siswa (3,8\%) menggunakan smartphone hanya beberapa kali dalam satu minggu. Situasi tersebut dapat ditanggapai secara positif oleh guru dengan cara memfasilitasi siswa untuk mengakses materi pelajaran yang sesuai dengan topik pembelajaran.Visualisasi frekuensi penggunaan smartphone dalam pembelajaran kimia disajikan pada Gambar 2.

\footnotetext{
${ }^{1}$ Yang, J.Y. and Che, P.-C., 2015. “Improving College Students English Learning with Dr. Eye Android Mid”. The Turkish Online Journal of Educational Technology, 14(2), 101-109.

2Sundari, T.T. 2015., "Effects of Mobile Phone Use on Academic Performance of College Going Young Adults in India”. International Journal of Applied Research, 1(9), 898-905.
} 




Gambar 2. Frekuensi penggunaan smartphone

Relatif tingginya intensitas penggunan smartphone dikalangan siswa perlu diarahkan ke program peningkatan kinerja belajar. Eksistensi smartphone tidak hanya digunakan sebagai media hiburan, namun diharapkan dapat digunakan sebagai media edukasi. Penelitian tentang dampak penggunaan mobile learning yang dilakukan Nasser (2014) menunjukkan bahwa pembelajaran dengan menggunakan teknologi mobile learning memperoleh hasil yang lebih tinggi dibandingkan dengan pembelajaran tradisional. Pembelajaran harus mampu menstimulus siswa untuk menemukan ide-ide kritis dan kreatif melalui pendekatan yang memanfaatkan teknologi. Dengan demikian, penggunaan teknologi yang tepat dapat meningkatkan prestasi belajar siswa. ${ }^{3}$

Hal-hal yang dilakukan siswa ketika menggunakan smartphone. Tanpa dipungkiri, perkembangan teknologi yang begitu pesat tidak dapat dicegah karena memberikan banyak keuntungan. Masyarakat modern yang hidup di era digital memilih menggunakan smartphone untuk memudahkan aktivitas interaksi maupun sarana komunikasi. Siswa sebagai bagian dari masyarakat modern perlu dibimbing dan diarahkan untuk menggunakan smartphone secara bijak dalam memperoleh pengetahuan. Beberapa hal yang dapat dilakukan siswa untuk mengoptimalkan proses pembelajaran antara lain keaktifan dalam mencari materi pelajaran dan mengumpulkan sumber informasi pendukung. Hasil survey tentang penggunaan smartphone dalam kegiatan pembelajaran kimia disajikan pada Tabel1.

Tabel 1. Penggunaan smartphone

\begin{tabular}{clc} 
No & Aktivitas & Persentase (\%) \\
\hline 1 & Mengakses materi pelajaran & 84,9 \\
\hline 2 & Mencari informasi & 84,9 \\
\hline 3 & Media social & 79,2 \\
\hline 4 & Mengirim dan menerima e-mail & 64,2 \\
\hline 5 & Mengunduh dan menonton video & 60,4 \\
\hline 6 & Membaca buku elektronik $(e-$ book $)$ & 28,3 \\
\hline 7 & Mengedit dokumen & 1,9 \\
\hline
\end{tabular}

Berdasarkan data pada Tabel 1 menunjukkan bahwa siswa secara positif menggunakan smartphone untuk mendukung kegiatan pembelajaran. Bahkan sebanyak 45 siswa $(84,9 \%)$ menggunakan smartphone sebagai sarana untuk mengakses materi pelajaran. Sedangkan hanya 1 siswa $(1,9 \%)$ yang menggunakan smartphone untuk mengedit dokumen pelajaran. Temuan lain menunjukkan bahwa sebanyak 42 siswa $(79,2 \%)$ memiliki kegemaran menggunakan media sosial. Penyelidikan lebih lanjut menemukan fakta bahwa media sosial tersebut digunakan antarsiswa sebagai sarana berkomunikasi di luar sekolah untuk menanyakan dan mendiskusikan tugas pembelajaran. Dampak penggunaan smartphone sebagai mobile jarak jauh sangat diminati siswa untuk meningkatkan hasil

\footnotetext{
${ }^{3}$ Nasser, R. 2014., “Using Mobile Device to Increase Student Academic Outcomes in Qatar”. Open Journal of Social
} Sciences, 2, 67-73. 
belajar. Selain itu, pembelajaran menggunakan smartphone tidak hanya berpeluang untuk membangun koneksi, tetapi juga membina kolaborasi kerja tim ${ }^{4}$ (Vázquez-Cano, 2014).

Berkaitan dengan pemanfaatan smartphone, butir9 dalam kuesioner meminta respons siswa tentang "Bagaimana cara yang dapat Anda lakukan untuk menunjang proses pembelajaran menggunakan smartphone?" Temuan menunjukkanadanya respons siswa sangat bervariasi, antara lain mencari informasi penting, saling berbagi informasi melalui grup kelas, mencari aplikasi pembelajaran, mencari materi pembelajaran, mendownload aplikasi berisi kumpulan soal, membaca beberapa artikel yang membuat penasaran, mencari materi yang tidak dimengerti, mencari beberapa materi pelajaran yang tidak tersedia di buku, dan menonton video-video tentang pembahasan materi pelajaran kimia. Respons tersebut menunjukkan bahwa smartphone membantu siswa untuk mengkonstruksi pengetahuan secara luas. Sedangkan butir 10 bertujuan untuk mengkonfirmasi penggunaan media sosial dalam pembelajaran kimia dikalangan siswa. "Apakah Anda berkomunikasi dengan teman sekelas menggunakan media sosial?”. Sebanyak 38 siswa $(71,7 \%)$ memberikan jawaban "sering”, 11 siswa (20,7\%) "kadang-kadang", dan 4 siswa (7,6\%) tidak menggunakan media sosial untuk hal-hal yang berhubungan dengan pelajaran. Responden memberikan alasan tentang penggunaan media sosial dikarenakan jarak antar rumah yang cukup jauh sehingga membutuhkan smartphone untuk memperlancar komunikasi, diskusi, dan berbagi informasi. Sedangkan siswa yang tidak memilih menggunakan media sosial cenderung menyukai interaksi antarsiswa secara langsung dalam proses pembelajaran.

Dalam praktiknya, smartphone tetap menjadi pilihan siswa dibandingkan perangkat lainnya karena dapat digunakan secara praktis tanpa membutuhkan ruang yang besar. Pesatnya perkembangan teknologi informasi akan membawa mobile learning menjadi alternatif pembelajaran di masa depan yang terus berkembang. Hasil survey menunjukkan bahwa 38 siswa $(71,7 \%)$ cenderung memilih menggunakan smartphone, sedangkan 15 siswa (28,3\%) memilih menggunakan laptop untuk mempermudah pembelajaran kimia.Visualisasi penggunaan perangkat pendukung dalam pembelajaran kimia disajikan pada Gambar 3.

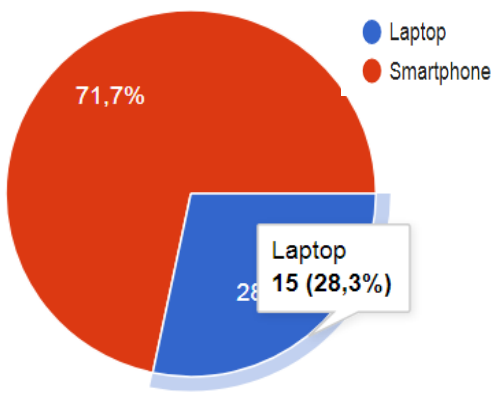

Gambar 3. Perangkat pendukung pembelajaran

Banyaknya siswa yang menggunakan smartphone dikarenakan perangkat tersebut memberikan kenyamanan dan kemudahan dalam penggunaannya sekaligus memiliki harga yang terjangkau. Survey menemukan sebanyak 22 siswa (41,5\%) menyatakan sangat nyaman, 29 siswa (54,7\%) cukup nyaman, dan hanya 2 siswa $(3,8 \%)$ tidak terlalu nyaman dalam menggunakan smartphone untuk menunjang pembelajaran. Hasil tersebut secara jelas disajikan pada Gambar 4. Penggunaan smartphone yang relatif mudah dapat digunakan sebagai alat untuk menjembatani antara mobilitas siswa dengan program pembelajaran untukmeningkatkan hasil belajar. Hal tersebut sejalan dengan penelitian yang telah dilakukan Awedh et al. (2014) menunjukkan bahwa penggunaan smartphone berpengaruh positif terhadap pembelajaran kolaboratif dan keterlibatan siswa secara aktif di kelas. ${ }^{5}$ Selain itu, hasil

\footnotetext{
${ }^{4}$ Vázquez-Cano, E., 2014.” Mobile Distance Learning with Smartphones and Apps in Higher Education”. Educational Sciences: Theory \& Practice, 14(4), 1505-1520.

${ }^{5}$ Awedh, M., Mueen, A., Zafar, B., and Manzoor, U., 2014. "Using Socrative and Smartphones for the Support of Collaborative Learning”. International Journal on Integrating Technology in Education, 3(4), 17-24.
} 
penelitian tersebut menunjukkan bahwa pembelajaran kolaboratif dan keterlibatan siswa mampu meningkatkan kinerja akademik.

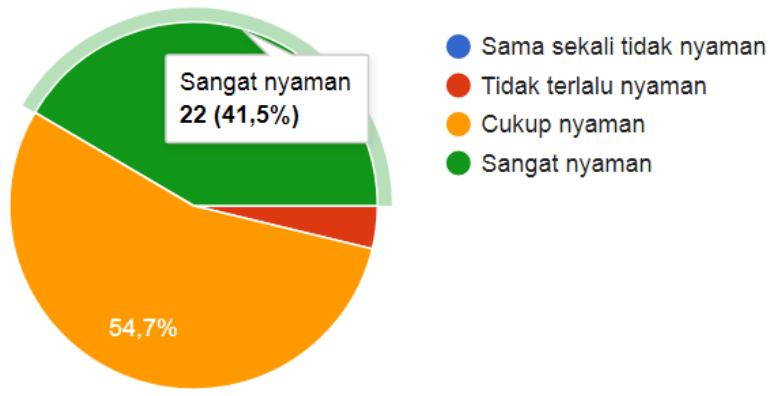

Gambar 4. Tingkat kenyamanan penggunaan smartphone

Berbagai penelitian terdahulu memberikan gambaran bahwa smartphone memiliki pengaruh positif untuk mengkonstruksi pengetahuan, keterampilan, dan sikap siswa. Ketiga aspek tersebut merupakan sasaran utama dalam pembelajaran kimia. Pembelajaran dengan menggunakan smartphone ditujukan kepada siswa untuk dapat mengambil dan menelusuri konten multimedia yang diinginkan melalui Android ${ }^{6}$ (Chang \& Lee, 2015). Sedangkan, AlFahad (2009) mengemukakan bahwa mobile learning dapat dijadikan sebagai metode untuk meningkatkan retensi siswa, keterampilan komunikasi, dan memperkaya pengalaman belajar siswa. $^{7}$ Selain itu, Seo \& Choi (2014) menegaskan bahwa penggunaan aplikasi mobile memberikan respon positif dalam kemudahan penggunaannya. ${ }^{8}$ Berdasarkan uraian tersebut, dapat disimpulkan bahwa penggunaan smartphone dapat dimanfaatkan sebagai suplemen pembelajaran kimia, baik di dalam maupun di luar sekolah. Melalui smartphone, pembelajaran kimia dapat dilakukan secara aktif, efektif, dan efisien untuk mendukung ketercapaian pembelajaran di kelas maupun di laboratorium.Smartphone merupakan sebuah perangkat multifungsi yang memberikan berbagai keuntungan bagi pengguna apabila dapat digunakan secara tepat.

\section{Simpulan}

Berdasarkan hasil penelitian dan pembahasan menunjukkan bahwa siswa menggunakan smartphone untuk mendukung program pembelajaran di dalam dan di luar kelas. Siswa lebih memilih menggunakan smartphone dalam pembelajaran dikarenakan adanya kemudahandalam mengakses informasi kapan saja dan di mana saja tanpa batasan ruang dan waktu. Hal-hal yang dilakukan siswa ketika menggunakan smartphone antara lain mengakses materi pelajaran, mencari informasi, menggunakan media sosial untuk berdiskusi, mengirim dan menerima e-mail, mengunduh dan menonton video yang berisi pembahasan materi pelajaran, membaca buku elektronik (e-book), serta mengedit dokumen.Pesatnya perkembangan teknologi informasi akan membawa mobile learning menjadi salah satu alternatif pembelajaran yang praktis di masa depan. Dengan demikian, guru perlu membimbing, mengarahkan, memfasilitasi, sekaligus mengoptimalkan penggunaan smartphone secara positif untuk meningkatkan motivasi dan hasil belajar siswa.

\footnotetext{
${ }^{6}$ Chang, H-J., and Lee, T-C., 2015. “The Study of Mobility Solution System Design on China Direct Selling Industry”. Open Journal of Social Sciences, 3, 139-147.

${ }^{7}$ Al-Fahad, F.N., 2009. "Students' Attitudes and Perceptions Towards The Effectiveness of Mobile Learning in King Saud University, Saudi Arabia”. The Turkish Online Journal of Educational Technology, 8(2), 111-119.

${ }^{8}$ Seo, W. and Choi, I-C. 2014., "The Effect of Using a Smart-Phone Speaking Application on Korean Middle School Students’ English Expression Learning and Satisfaction”. Multimedia-Assisted Language Learning, 17(1), 34-57.
} 


\section{Daftar Pustaka}

Al-Fahad, F.N., 2009. "Students' Attitudes and Perceptions Towards The Effectiveness of Mobile Learning in King Saud University, Saudi Arabia”. The Turkish Online Journal of Educational Technology, 8(2), 111-119.

Awedh, M., Mueen, A., Zafar, B., and Manzoor, U., 2014. "Using Socrative and Smartphones for the Support of Collaborative Learning”. International Journal on Integrating Technology in Education, 3(4), 17-24.

Boyinbode, O. and Fasunon, D., 2015. "Deploying an Interactive Mobile Learning System in the Classroom”. International Journal of u- and e- Service, Science and Technology, 8(4), 321-330.

Chang, H-J., and Lee, T-C., 2015. "The Study of Mobility Solution System Design on China Direct Selling Industry”. Open Journal of Social Sciences, 3, 139-147.

Chuang, Y. T., 2014. "Increasing Learning Motivation and Student Engagement through the Technology-Supported Learning Environment”. Creative Education, 5, 1969-1978.

Herrington, A., 2008. Adult Educators' Authentic Use of Smartphones to Create Digital Teaching Resources. in Hello! Where Are You in The Landscape of Educational Technology?. Proceedings Ascilite $\quad$ Melbourne $2008 . \quad$ Retrieved from http://ro.uow.edu.au/cgi/viewcontent.cgi?article=2009\&context= edupapers, on May 15, 2016.

Hess, S. 2014., "Digital Media and Student Learning: Impact of Electronic Books on Motivation and Achievement”. New England Reading Associatiion Journal, 49 (2), 35-39.

Martono, K.T. and Nurhayati, O.D., 2014. "Implementation of Android Based Mobile Learning Application As a Flexible Learning Media”. International Journal of Computer Science Issues, 11(1), 168-174.

Meister, J. 2011., “2011: The Year of the Media Tablet As a Learning Tool”. Proquest, 65(4), 28-31.

Nasser, R. 2014., "Using Mobile Device to Increase Student Academic Outcomes in Qatar”. Open Journal of Social Sciences, 2, 67-73.

Parise, S. and Crosina, E. 2012., "How a Mobile Social Media Game Can Enhance the Educational Experience”. MERLOT Journal of Online Learning and Teaching, 8(3), 209-222.

Peraturan Menteri Pendidikan dan Kebudayaan Nomor 72 Tahun 2013 tentang Pendidikan Layanan Khusus.

Rossing, J.P., Miller, W. M., Cecil, A.K., and Stamper, S.E. 2012., "iLearning: The future of higher education? Student perceptions on learning with mobile tablets". Journal of the Scholarship of Teaching and Learning, 12(2), 1-26.

Sarrab, M., Elgamel, L., and Aldabbas, H. 2012., "Mobile Learning (M-Learning) and Educational Environments". International Journal of Distributed and Parallel Systems, 3(4), 31-38.

Seo, W. and Choi, I-C. 2014., "The Effect of Using a Smart-Phone Speaking Application on Korean Middle School Students’ English Expression Learning and Satisfaction”. Multimedia-Assisted Language Learning, 17(1), 34-57.

Shi, W.-Z., Sun, J., Xu, C., and Huan, W. 2016., “Assessing the Use of Smartphone in the University General Physics Laboratory”. Eurasia Journal of Mathematics, Science \& Technology Education, 12(1), 125-132.

Sundari, T.T. 2015., "Effects of Mobile Phone Use on Academic Performance of College Going Young Adults in India”. International Journal of Applied Research, 1(9), 898-905.

StatCounter., 2017. Top 8 Mobile \& Tablet Operating Systems in Indonesia from July 2016 to July 2017. Retrieved from http://gs.statcounter.com, on July 24, 2017.

Vázquez-Cano, E., 2014.” Mobile Distance Learning with Smartphones and Apps in Higher Education”. Educational Sciences: Theory \& Practice, 14(4), 1505-1520.

Woodcock, B., Middleton, A., and Nortcliffe, A., 2012. "Considering The Smartphone Learner: An Investigation into Student Interest in The Use of Personal Technology to Enhance Their Learning”. Student Engagement and Experience Journal, 1(1), 1-15.

Yang, J.Y. and Che, P.-C., 2015. "Improving College Students English Learning with Dr. Eye Android Mid”. The Turkish Online Journal of Educational Technology, 14(2), 101-109. 